\title{
Strategi Manjemen Mutu Perguruan Tinggi Swasta dengan Kesiapan Mahasiswa Dalam Menghadapi Masyarakat Ekonomi Asean
}

\author{
${ }^{1}$ Rudi Hariawan, ${ }^{2}$ Haromain, ${ }^{3}$ Hadi Gunawan Sakti \\ ${ }^{1}$ Program Studi Administrasi Pendidikan, Universitas Pendidikan Mandalika \\ ${ }^{2}$ Program Studi Administrasi Pendidikan, Universitas Pendidikan Mandalika \\ ${ }^{3}$ Program Studi Teknologi Pendidikan, Universitas Pendidikan Mandalika \\ Email: rudiap@ikipmataram.ac.id.haromain@ikipmataram.ac.id,gunawansakti33@gmail.com
}

\begin{abstract}
Abstrak. Kesiapan lulusan perguruan tinggi swasta dalam menghadapi pasar ekonomi asean sangat dipengaruhi oleh manajemen mutu perguruan tinggi, diantaranya; proses pembelajaran yang berkualitas; sarana-prasarana yang memadai; dan lingkungan belajar yang aman, nyaman dan menyenangkan. Tujuan penelitian ini adalah untuk mengetahui strategi manajemen perguruan tinggi dalam menghadapi pasar ekonomi asean. Hasil penelitian ini menunjukan ketiga komponen kualitas pembelajaran, kualitas sarana-prasarana, dan kualitas lingkungan belajar secara bersama-sama memiliki pengaruh yang signifikan terhadap kesiapan mahasiswa dalam menghadapi AEC. Akan tetapi secara parsial variabel untuk kualitas pembelajaran tidak terlalu signifikan terhadap kesiapan mahasiswa dalam menghadapi MEA.
\end{abstract}

Keywords: Manajemen Mutu, Kesiapan Mahasiswa, Masyarakat Ekonomi Asean.

\section{PENDAHULUAN}

Asean vision 2020 "hidup berdampingan secara damai dan menciptakan perdamian internasional", yang selanjutnya akan direalisasikan dengan meningkatkan kualitas sumber daya manusia, ekonomi, lingkungan hidup, sosial, teknologi, hak cipta intelektual, keamanan dan perdamaian, serta pariwisata yang dilalukan melalui serangkaian aksi bersama dalam bentuk hubungan kerjasama yang baik dan saling menguntungkan diantara negara-negara anggota Asean (Wangke, 2015:6). Tujuan akhirnya adalah integrasi ekonomi atau yang disebut sebagai Asean Economic Community (AEC).

Posisi Indonesia pada era perdagangan bebas Asean telah melahirkan regulasi penting yaitu Undang Undang Republik Indonesia nomor 7 tahun 2014 tentang Perdagangan, yang telah diperkenalkan ke masyarakat sebagai salah satu strategi Indonesia membendung banjirnya produk impor ke Indonesia (Republic Of Indonesia, 2014). Regulasi tersebut terasa penting bila mempertimbangkan kondisi perdagangan Indonesia selama ini belum optimal memanfaatkan potensi pasar Asean. Pemberlakuan AEC memberikan semangat pada negara anggota Asean agar produk dan jasanya maju dalam persaingan.

Dengan memperhatikan jumlah penduduk Indonesia yang tidak kurang 265 juta jiwa dengan kategori usia produktif (usia 14-64 tahun) sekitar 179,13 juta jiwa atau sekitar 67,6 persen (Bappenas, 2018). Jumlah usia produktif ini disebut juga sebagai bonus demografi bagi Indonesia

Namun ada persoalan mendasar yang masih dihadapi bangsa Indonesia terkait diberlakukannya AEC, yakni belum semua masyarakat memahami esensi dengan diberlakukannya pasar global di tingkat Asean ini. Padahal Malaysia dan Singapura telah mensosialisasikan kebijakan AEC kepada warganya sejak lama, sementara Thailand dan Philipina merespons dengan mengajarkan Bahasa Indonesia. Maka "kesiapan" menjadi kata kunci (key word) upaya meningkatkan daya saing, yang pada gilirannya diharapkan akan menciptakan keunggulan-keunggulan (competitive advantage) di masa depan.

Menurut data Badan Pusat Statisti (BPS) Provinsi Nusa Tenggara Barat (NTB) yang dirangkum oleh Mutia Fauzia bahwa "jumlah penduduk Provinsi NTB 4.955.578 jiwa (1 Juli 2017) dengan tingkat pertumbuhan ekonomi 7,1 persen melebihi tingkat pertumbuhan 
ekonomi nasional. Tingkat pengangguran 3,32 persen dan kemiskinan 15,05 persen. Prospek perekonomian NTB ke depan diprediksi akan semakin kuat. Salah satunya dikarenakan investasi pembangunan yang sedang marak dilakukan, seperti Kawasan Eonomi Khusus (KEK) Mandalika dan pembangunan Pelabuhan Gili Mas" (Kompas.com21/04/2018).

Data ini menunjukkan provinsi NTB termasuk pasar potensial, peluang kerja akan banyak tersedia kedepan, kesempatan kerja akan semakin luas. Yang menjadi kekhawatiran banyak perguruan tinggi adalah ketidaksiapan angkatan kerja dalam negeri bersaing dengan tenaga kerja asing. Sehingga dapat mengakibatkan pengangguran dikalangan terdidik. Pendidikan harus membantu pengembangan peserta didik dalam konsep life skill yang menyiapkan peserta didik agar memiliki kecakapan hidup yang bermakna dan berguna di kemudian hari. Pendidikan yang dilaksanakan harus sesuai dengan kebutuhan dunia kerja, sehingga keterserapan lulusan oleh dunia kerja menjadi tinggi (Muhson, Wahyuni, \& Mulyani, 2012).

Dalam beberapa kasus saja misalnya penulis menjumpai para lulusan dari jurusan administrasi pendidikan dari Universitas Pendidikan Mandalika bekerja di luar bidang pendidikan, mereka mengikuti proses rekrutmen secara terbuka dari berbagai bidang keahlian dan disiplin ilmu, hal ini juga membutuhkan kajian lain sebagai dampak pengiring lulusan perguruan tinggi

Pasar ekonomi Asean telah membuka kesempatan kerja yang luas, jika para lulusan perguruan tinggi tidak mampu atau belum siap berkompetisi di pasar global, maka ini menunjukkan para lulusan belum sesuai dengan kebutuhan pasar kerja. Karena itulah perlu adanya hubungan yang saling menguntungkan antara perguruan tinggi dengan dunia kerja usaha/industri atau yang disebut dengan hubungan simbiostik mutualisme (Sonhadji, 1992).

Dalam kaitannya dengan relevansi pendidikan, menurut Kamus Besar Bahasa Indonesia (2005: 943) relevansi diartikan sebagai "hubungan; kesesuaian; kaitan dengan tujuan; berguna secara langsung dengan apa yang dibutuhkan". Relevansi berarti (1) terkait dengan apa yang sedang terjadi atau dibahas, (2) benar dan atau sesuai untuk tujuan tertentu. Sebagai kata benda berarti tingkat keterkaitan atau kebermaknaan sesuatu dengan apa yang terjadi atau dibahasnya. Relevansi pendidikan tinggi bagi mahasiswa terkait dengan lulusan yang akan menyesuaikan diri dengan dan berpartisipasi dalam dunia kerja nantinya (Muhson et al., 2012)

Kondisi ini mendapat respon positif secara serius oleh perguruan tinggi untuk menyiapkan mahasiswa menjadi lulusan yang mampu berkompetisi pada pasar gelobal yaitu AEC yang sudah dimualai sejak awal januari 2016 lalu agar relevan dengan kebutuhan pasar kerja. Di Pekanbaru misalnya beberapa perguruan tinggi swasta membuka kelas karyawan karena peminat kelas regular dengan kelas karyawan hampir sama besar antara 40 persen sampai 45 persen dari jumlah total mahasiwa setiap tahun ajaran baru (Widayat, 2018). Menurutnya "dibukanya kelas karyawan tidak semata hanya mencari income atau bisnis bagi perguruan tinggi atau institusi penyelenggaran pendidikan tinggi, tetapi juga wajib memperhatikan kualitas dari lulusan dan bagaimana proses belajar mengajar yang dilakukan" (Widayat, 2018:200).

Menurut Sonhadji (1992) perguruan tinggi tidak boleh lepas dari perkembangan masyarakat, kehadiran perguruan tinggi beserta program pendidikan harus selalu relevan dengan kebutuhan masyarakat di sekelilingnya. Demikian juga Muh Fitrah, Ruslan (2018:77) "mutu lulusan berkaitan dengan ciri khas yang ditentukan oleh perguruan tinggi serta menunjukkan kesiapan lulusan untuk terjun dan berkarya langsung di masyarakat dan dunia kerja sebagaimana diharapkan oleh pelanggan dan stakeholders".

Perguruan tinggi hendaknya lebih responsip dengan kebutuhan masyarakat, melakukan asessmen kebutuhan yang memenuhi tiga prinsip yaitu: (1) proaktif dalam mengidentifikasi potensial untuk memperbaiki kinerja perguruan tinggi; (2) berkesinambungan dalam memonitor perkembangan menuju pencapaian tujuan perguruan tinggi yang harapkan; dan (3) reaktif, kapanpun terdapat tujuan, strategic, 
taktik, atau permasalahan baru (Sonhadji, A. 2014).

Pada program administrasi pendidikan di Universitas Pendidikan Mandalika, sejak tahun 2009 telah berupaya meningkatkan kualitas pelayanan pendidikan dalam proses pembelajaran, penambahan sarana-prasarana, dan perbaikan lingkungan belajar dengan memperoleh dukungan penuh dari yayasan pembina Universitas Pendidikan Mandalika Pada tahun 2017 semua jurusan termasuk Institusi telah terakreditasi B. Karena salah satu pertimbangan mahasiswa memilih perguruan tinggi adalah status akreditasinya, point akreditasi menjadi perhatian mahasiswa dalam memilih kampus dengan pertimbangan bahwa ketika mereka lulus bisa ikut rekrutmen CPNS dan bekerja pada perusahaanperusahaan yang berkualitas (Widayat, 2018)

Kualitas lulusan bukan hanya berbicara area local tetapi sudah masuk pasar global. Kualitas lulusaan tentu dimulai dengan proses yang baik. Peningkatan kualitas pembelajaran pada jurusan administrasi pendidikan dilakukan melalui peningkatan kualitas tenaga pendidik/dosen karena proses yang baik dimulai dengan kualitas dosen yang baik (Widayat, 2018:204). Universitas Pendidikan Mandalika melakukan rekrutmen tenaga dosen baru yang berkualifikasi minimal strata dua (S2), sedangkan dosen yang masih sarjana (S1) tidak diperkenankan mengampu mata kuliah, kecuali dosen senior dengan jabatan fungsional minimal Lektor. Sehingga dosen yang masih berkualifikasi S1 diwajibkan menempuh pendidikan lanjutan dengan biaya penuh dari yayasan pembina Universitas Pendidikan Mandalika. Jumlah dosen Universitas Pendidikan Mandalika sebanya 241 dosen dan mahasiswa 6.427, dengan rasio 1:26. Pada jurusan administrasi pendidikan, Universitas Pendidikan Mandalika, memiliki mahasiswa 493, dengan 15 dosen 7 Dosen berkualifikasi Doktor termasuk 1 dosen yang sedang menempuh studi lanjut Doktor (S3). Rasio dosen dengan mahasiswa 1:33. (https://forlap.ristekdikti.go.id)

Universitas Pendidikan Mandalika sebagai perguruan tinggi swasta memahami bahwa keterbatasan sumberdaya yang dimiliki, akan tetapi terus berupaya meningkatkan kualitas pelayanan kepada mahasiswa dengan menyediakan sarana-prasarana perkuliahan yang memadai, misalnya; semua ruang kelas di tiap-tiap gedung sudah dilengkapi dengan kursi, meja, whiteboard, dan LCD proyektor, layanan perpustakaan, hotspot gratis di semua area kampus; dan layanan akademik semua berbasis online.

Lingkungan belajar dikampus dapat dibedakan menjadi dua, yaitu; lingkungan fisik dan lingkungan social. Sederhananya adalah bahwa lingkungan fisik yang dimaksud adalah benda/media yang memiliki bentuk fisik yang dapat sentuh dan dilihat, sedangkan lingkungan social adalah interaksi yang terjadi dengan orang-orang yang berada dalam lingkungan kampus.

Lingkungan fisik dan sosial di kampus Universitas Pendidikan Mandalika dalam menunjang pembelajaran di dalam maupun di luar kelas telah dikelola dengan baik, misalnya; kebersihan lingkungan, penataan taman, gazebo (area duduk dan bersantai). Sedangkan untuk lingkungan sosial yang harmonis dan bersahaja antara semua civitas akademik dilakukan melalui pelayanan kepada mahasiswa dengan ramah dan segera, pengamalan nilai keagmaan dan budaya tinggi. Lingkungan ini secara menyeluruh dapat menambah motivasi para mahasiswa untuk terus belajar meningkatkan kualitas dirinya.

Dengan berlandaskan pada upaya-upaya peningkatan kualitas proses pembelajaran, kualitas sarana-prasarana belajar yang memadai, dan kualitas lingkungan belajar yang lebih kondusif, aman dan menyenangkan di Universitas Pendidikan Mandalika dalam mempersiapkan mahasiswa yang mampu bersaing pada masyarakat ekonomi Asean setelah meraka lulus nanti. Pengelolaan ketiga komponen kualitas inilah yang menjadi pertimbangan untuk melakukan penelitian tentang manajemen mutu di perguruan tinggi swasta dengan judul "hubungan manajemen mutu perguruan tinggi swasta dengan kesiapan mahasiswa dalam menghadapi masyarakat ekonomi asean di Universitas Pendidikan Mandalika"

Rumusan masalah yang utama dalam penelitian ini adalah "apakah ada hubungan manajemen mutu perguruan tinggi swasta 
dengan kesiapan mahasiswa dalam menghadapi masyarakat ekonomi asean di Universitas Pendidikan Mandalika"? yang diuraikan kedalam beberapa pertanyaan berikut:

1) Apakah ada hubungan kualitas pembelajaran dengan kesiapan mahasiswa dalam menghadapi MEA?

2) Apakah ada hubungan kualitas saranaprasarana dengan kesiapan mahasiswa dalam menghadapi MEA?

3) Apakah ada hubungan kualitas lingkungan belajar dengan kesiapan mahasiswa dalam menghadapi MEA?

4) Apa ada pengaruh kualitas pembelajaran, kualitas sarana-prasarana, dan kualitas lingkungan belajar secara bersama-sama terhadap kesiapan mahasiswa dalam menghadapi MEA?

Sedangkan hepotesis yang diajukan dalam penelitian ini adalah

1) Ada hubungan yang signifikan antara kualitas pembelajaran dengan kesiapan mahasiswa menghadapi MEA

2) Ada hubungan yang signifikan antara kualitas sarana-prasarana dengan kesiapan mahasiswa menghadapi MEA

3) Ada hubungan yang signifikan antara kualitas lingkungan belajar dengan kesiapan mahasiswa menghadapi MEA

4) Terdapat hubungan yang signifikan antara kualitas pembelajaran, kualitas saranaprasarana, dan lingkungan pembelajaran secara bersama-sama dengan kesiapan mahasiswa menghadapi MEA.

\section{METODE}

\section{Subyek Penelitian}

Subyek penelitian ini adalah para mahasiswa akhir dari angkatan 2015 yang tercatat masih aktif sebanyak 50 mahasiswa pada program studi administrasi pendidikan di Universitas Pendidikan Mandalika, yang diperkirakan akan segera lulus dan dianggap paling mewakili tujuan penelitian.

\section{Obyek Penelitian}

Berdasarkan hepotesis penelitian yang diajukan diidentifikasi tiga variabel independen dan satu variabel dependen. Untuk variabel independen $(X)$, yaitu; $X_{1}=$ kualitas pembelajaran, $X_{2}=$ kualitas sarana-prasarana,
$X_{3}=$ kualitas lingkungan belajar, dan kesiapan mahasiswa menghadapi MEA sebagai dependen (Y). Diagram hubungan antar variable pada gambar 1.

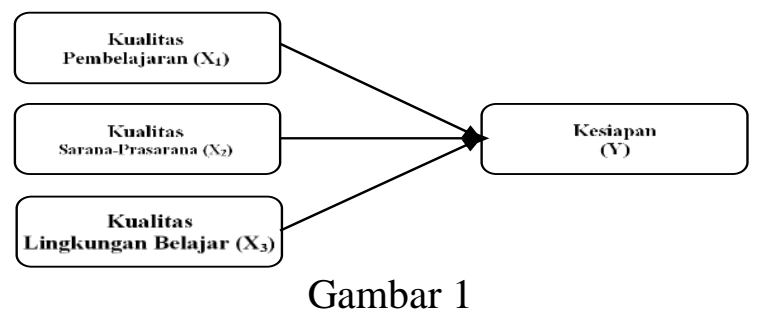

Formulasi hubungan antar variable

\section{Instrument}

Instrument penelitian ini menggunakan angket dan dokumentasi. Instrumen penelitian berupa item-item pernyataan dengan lima skala pilihan jawaban sesuai kondisi yang dialami subyek itu sendiri. Pilihan jawaban sebagai berikut:

Tabel 1. Skala pilihan Jawaban

\begin{tabular}{|c|c|c|c|c|c|}
\hline Skor & $\mathbf{1}$ & $\mathbf{2}$ & $\mathbf{3}$ & $\mathbf{4}$ & $\mathbf{5}$ \\
\hline $\begin{array}{c}\text { Pilihan } \\
\text { Jawaban }\end{array}$ & $\begin{array}{c}\text { Sangat } \\
\text { Tidak } \\
\text { Setuju }\end{array}$ & $\begin{array}{c}\text { Tidak } \\
\text { Setuju }\end{array}$ & $\begin{array}{c}\text { Kurang } \\
\text { Setuju }\end{array}$ & Setuju & $\begin{array}{c}\text { Sangat } \\
\text { Setuju }\end{array}$ \\
\hline
\end{tabular}

Sedangkan dokumentasi adalah untuk mengumpulakan data tentang jumlah mahasiswa semester akhir yang masih aktif sampai April tahun 2018.

\section{Analisis Data}

Analisis regresi berganda digunakan untuk dapat menunjukkan hubungan variabel independen terhadap variabel dependennya. Maka sebelum itu terlebih dahulu dilakukan uji asumsi klasik yang terdiri dari uji normalitas, uji multikolinieritas, uji autokorelasi, dan heteroskedastisitas. Hasil pengujian kemudian dijadikan dasar untuk menarik kesimpulan. Dalam penelitian ini analisis data akan menggunakan bantuan program SPSS versi 16 for Window.

\section{HASIL DAN PEMBAHASAN}

Dalam melakukan uji hepotesis untuk mencari hubungan antar variable dengan menggunkan teknik analisis (1) Uji Parsial (Uji t), dan (2) Uji Simultan (Uji F), sebelumnya telah dilakukan uji validitas dan realiabilitas dengan hasil memenuhi, sehingga dapat dilanjutkan pada uji hepotesis. 


\section{Uji Parsial (Uji t)}

Berdasarkan hasil perhitungan analisis regresi linier berganda dengan menggunakan SPSS 16 for windows di peroleh koefisien regresi tingkat kesalahan $(\alpha=5 \%)$ sebagai berikut:

Tabel 2. Hasil Uji Parsial (Uji t)

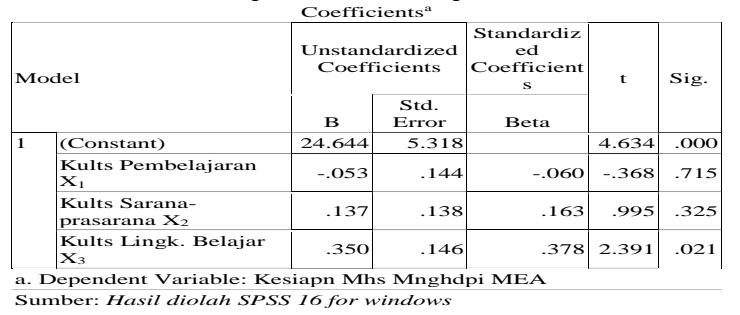

Uji t untuk $X_{1}$

Pada Tabel 2 untuk variable kualitas kembelajaran $\left(X_{1}\right)$ nilai $\mathrm{t}=-.368$ pada $\alpha=$ 0.715 . atau dapat dikatakan $(-0.368<0.715)$.

Dengan demikian dapat disimpulkan bahwa variable kualitas pembelajaran $\left(\mathrm{X}_{1}\right)$ tidak berpengaruh terhadap variable kesiapan mahasiswa menghadapai MEA (Y).

\section{Uji t untuk $\mathrm{X}_{2}$}

Pada Tabel 2 untuk variable kualitas sarana \& prasarana $\left(X_{2}\right)$ nilai $\mathrm{t}=0.995$ pada $\alpha=$ 0.325 atau dapat dikatakan $(0.995>0.325)$.

Dengan demikian dapat disimpulkan bahwa variable kualitas sarana \& prasarana $\left(\mathrm{X}_{2}\right)$ berpengaruh terhadap variable kesiapan mahasiswa menghadapai MEA (Y).

\section{Uji t untuk $\mathrm{X}_{3}$}

Pada Tabel 2 untuk variable kualitas lingkungan belajar $\left(X_{3}\right)$ nilai $\mathrm{t}=2.391$ dan nilai $\alpha=0.021$. atau dapat dikatakan (2.391 > 0.021)

Dengan demikian dapat disimpulkan bahwa variable kualitas lingkungan belajar $\left(X_{3}\right)$ Berpengaruh terhadap variable kesiapan mahasiswa menghadapai MEA. (Y).

\section{Uji Simultan (Uji F)}

Nilai Uji $F$ dengan menggunakan bantuan aplikasi SPSS versi 16 for windows. Selanjutnya nilai Uji F secara bersama-sama $\mathrm{X}_{1}, \mathrm{X}_{2}$, dan $\mathrm{X}_{2}$ akan dibandingkan dengan taraf signifikansi $\alpha=5 \%$ dengan $N=50$. Perumusan dalam pengambilan keputusannya:

$\mathrm{H}_{0}$ : Tidak ada pengaruh $\mathrm{X}_{1}, \mathrm{X}_{2}$, dan $\mathrm{X}_{3}$ secara besama-sama terhadap $\mathrm{Y}$

$\mathrm{H}_{1}$ : Ada pengaruh $\mathrm{X}_{1}, \mathrm{X}_{2}$, dan $\mathrm{X}_{3}$ secara besama-sama terhadap $\mathrm{Y}$
Tabel 3. Hasil Uji Simultan (Uji F)

\begin{tabular}{|c|c|c|c|c|c|c|}
\hline \multicolumn{7}{|c|}{ ANOVA $^{\mathrm{b}}$} \\
\hline \multicolumn{2}{|c|}{ Model } & $\begin{array}{l}\text { Sum of } \\
\text { Squares }\end{array}$ & $\mathrm{df}$ & $\begin{array}{l}\text { Mean } \\
\text { Square }\end{array}$ & $\mathrm{F}$ & Sig. \\
\hline \multirow[t]{3}{*}{1} & $\begin{array}{l}\text { Regressio } \\
\mathrm{n}\end{array}$ & 81.370 & 3 & 27.123 & 3.857 & $.015^{\mathrm{a}}$ \\
\hline & Residual & 323.510 & 46 & 7.033 & & \\
\hline & Total & 404.880 & 49 & & & \\
\hline \multicolumn{7}{|c|}{$\begin{array}{l}\text { a. Predictors: (Constant), Kults Lingk. Belajar, Kults Pembelajaran, } \\
\text { Kults Sarana-prasarana }\end{array}$} \\
\hline & pendent $\mathrm{Va}$ & able: Kesiapn & Mhs M & ghdpi ME $A$ & & \\
\hline
\end{tabular}

Sumber: Hasil diolah SPSS 16 for windows

Terlihat pada table 3 nilai $\mathrm{Uji} F=3,857$. taraf signifikansi $\alpha=5 \%$ sebesar 0.015 . (3,857 $>0.015)$ maka $\mathrm{H}_{0}$ ditolak dan $\mathrm{H}_{1}$ diterima. Sehingga dapat dikatakan bahwa secara simultan atau bersama $\mathrm{X}_{1}, \mathrm{X}_{2}$, dan $\mathrm{X}_{3}$ berpengaruh terhadap Y.

Dengan demikian dapat disimpulkan bahwa secara bersama-sama variable kualitas pembelajaran $\left(\mathrm{X}_{1}\right)$, kualitas Sarana-prasarana $\left(\mathrm{X}_{2}\right)$ dan kualitas lingkungan belajar $\left(\mathrm{X}_{3}\right)$ berpengaruh terhadap kesiapan mahasiswa menghadapai MEA. (Y).

\section{Hasil dan Pembahasan}

Berdasarkan hasil penelitian dapat dikemukakan bahwa kualitas pembelajaran, kualitas sarana-prasarana, dan kualitas lingkungan belajar secara bersama-sama berpengaruh positif terhadap kesiapan mahasiswa dalam menghadapi masyarakat ekonomi Asean yang telah diberlakukan di awal tahun 2016 lalu. Akan tetapi pada tahap uji secara parsial, menunjukkan bahwa kualitas pembelajaran tidak berpengaruh signifikan terhadap kesiapan mahasiswa dalam menghadapi masyarakat ekonomi asean. Adapun yang berpengaruh signifikan terhadap kesiapan mahasiswa dalam menghadapi masyarakat ekonomi asean adalah kualitas sarana-prasarana dan kualitas lingkungan belajar. Secara berurutan akan dibahas masingmasing hubungan antara kualitas pembelajaran, kualitas sarana-prasarana, dan kualitas lingkungan belajar dengan kesiapan mahasiswa dalam mengahadapi MEA, sebagai berikut:

\subsection{Kualitas Pembelajaran}

Kualitas pembelajaran dari koefisien korelasi berganda hanya mampu memberikan nilai sebesar 0,053 atau dapat dikatakan bahwa setiap penambahan 1 (satu) nilai kualitas pembelajaran akan meningkatkan kesiapan mahasiswa menghadapi MEA sebesar 0,053. 
Dan secara parsial dalam penelitian ini kualitas pembelajaran tidak signifikan tehadap kesiapan mahasiswa menghadapai MEA.

Dalam Undang Undang Republik Indonesia Nomor 20 tahun 2003 tentang Sistem Pendidikan Nasional dijelaskan bahwa pembelajaran adalah proses interaksi peserta didik dengan pendidik dan sumber belajar pada suatu lingkungan belajar (Republic Of Indonesia, 2003). Kalau dicermati seharusnya kualitas pembelajaran akan berkorelasi positif dengan hasil belajar yaitu yaitu dalam hal ini kesiapan mahasiswa dalam menghadapi MEA.

Padahal secara konseptual proses pembelajaran dikelas sebagai inti dalam kegiatan penyelenggaraan pendidikan di perguruan tinggi. Dalam proses pembelajaran akan terbangun hubungan kerjasama dalam suasana kondusif dan menyenangkan, mampu menyerap dan memahami pelajaran yang disampaikan dosen dengan metode yang bervariasi. Dengan demikian dapat dikatakan bahwa kualitas lulusan merupakan cerminan kualitas proses pembelajaran yang dilaksanakan oleh dosen (Widayat, 2018). Pembelajaran adalah suatu proses dimana lingkungan seseorang secara sengaja dikelola dan ia turut serta dalam tingkah laku tertentu dalam kondisi-kondisi khusus atau menghasilkan respon terhadap situasi tertentu (Sagala, 2003:61). Dari penjelasan pendapat ahli di atas sebenarnya secara konseptual bahwa kualitas pembelajaran juga sagat dipengaruhi oleh lingkungan belajar.

\subsection{Kualitas Sarana-prasarana}

Berdasarkan hasil linier berganda nilai koefisien regresi berganda kualitas saranaprasarana sebesar 0,995 menyatakan bahwa setiap penambahan 1 (satu) akan meningkatkan kesiapan mahasiswa dalam menghadapi MEA sebesar 0,995. Secara parsial variable kualitas sarana-prasarana berpengaruh terhadap kesiapan mahasiswa dalam menghadapai MEA.

Fasilitas penunjang yang berkualitas dalam perkuliahan dibidang eksakta membutuhkan alat-alat praktikum, uji laboratorium dan lainnya, dibutuhkan biaya yang cukup tinggi untuk peralatan yang berkualitas (Widayat, 2018). Kualitas fasilitas pendukung seperti laboratorium, kebun percobaan, perpustakaan yang memadai, serta akses staf dan mahasiswa ke Internet (Effendi, 2003). Sarana-prasarana adalah unsur penunjang dalam pelaksanaan tri dharma perguruan tinggi. Dalam standar saranaprasarana pendidikan dengan criteria minimal tentang ruang belajar, perpustakaan, tempat bermain, tempat berkreasi dan berekreasi, serta tersedianya sumber belajar yang diperlukan untuk menunjangg proses pembelajaran, termasuk penggunaan teknologi informasi dan komunikasi.

Semua fasilitas pendukung dan penunjang proses pembelajaran harus tersedia di perguruan tinggi dan dimanfaatkan sebagai sumber belajar dalam mengembangkan kemampuan dan kompetensi lulusan perguruan tinggi. Lulusan yang kompeten sangat didukung oleh pemanfaatan sumber belajar secara maksimal dalam proses pembelajaran. Sebenarnya jika dilihat bahwa kualitas sarana-prasarana dan proses pembelajaran memiliki korelasi yang positif dalam menghasilkan lulusan yang siap menghadapi dunia kerja di masa depan

\subsection{Kualitas Lingkungan Belajar}

Berdasarkan hasil linier berganda nilai Koefisien regresi berganda kualitas lingkungan belajar sebesar 0,350 artinya setiap penambahan 1 (satu) nilai kualitas lingkungan belajar yang kondusif akan meningkatkan kesiapan mahasiswa dalam menghadapi AEC sebesar 0,350. Dan hasil uji parsial kualitas lingkungan belajar ada pengaruhnya terhadap kesiapan mahasiswa menghadapai AEC

Pada pembahasan proses pembelajaran juga sudah dijelaskan bahwa kualitas lingkungan belajar berpengaruh terhadap prestasi belajar. Jika dalam hasil penelitian ini ditemukan bahwa kualitas lingkungan belajar sangat berpengaruh signifikan terhadap kesiapan para mahasiswa menghadapai AEC, setelah mereka lulus nanti, hal ini bisa saja terjadi karena secara historis perguruan tinggi yang diteliti memiliki sejarah yang kurang baik tentang keamanan dan kenyaman.

$$
\text { Menurut Soemanto }
$$

mengemukakan bahwa lingkungan mencakup segala material dan stimuli di dalam dan di luar diri individu, baik yang berupa fsikologis, maupun sosio-kultural. Sedangkan menurut 
Suwarno (2006) lingkungan belajar adalah lingkungan yang melingkupi terjadinya proses pendidikan. Dengan demikian jika dihubungkan dengan penelitian ini dukungan lingkungan belajar yang kondusif sangat berpengaruh terhadap proses pendidikan di perguruan tinggi. Sebagaimana lokasi penelitian dalam kajian ini, memang secara historis memiliki pengalaman yang tidak menyenangkan. Sehingga lingkungan belajar menjadi variable yang sangat dominan dalam membentuk lulusan yang siap bekerja di masa depan.

\subsection{Hubungan secara Simultan}

Secara bersama-sama koefisien determinasi $\mathrm{R}^{2}$ (R-Square) sebesar 3,857 atau $38,57 \%$. Dengan kata lain kualitas pembelajaran, kualitas sarana-prasarana, dan kualitas lingkungan belajar secara bersamasama berpengaruh terhadap kesiapan mahasiswa dalam menghadapi MEA.

Kesiapan mahasiswa dalam menghadapi MEA ini, secara simultan dipengaruhi oleh kualitas pembelajaran yang dilaksanakan, kualitas sarana-prasarana yang memadai, dan iklim lingkungan belajar yang kondusif, aman dan menyenangkan. Jika hasil kajian ini diterapkan di perguruan tinggi, khususnya di lokasi penelitian ada baiknya memperhatikan variable kualitas lingkungan belajar, tetapi tidak mengabaikan variable lain, karena semua komponen juga memiliki pengaruh terhadap penyelenggaraan pendidikan di perguruan tinggi yang lebih baik.

\section{Simpulan}

Berdasarkan hasil temuan penelitian tentang hubungan kualitas pembelajaran, kualitas sarana-prasarana dan kualitas lingkungan belajar dengan kesiapan mahasiswa dalam menghadapi MEA pada jurusan administrasi pendidikan di Universitas Pendidikan Mandalika dapat di simpulkan:

- Kualitas pembelajaran tidak berpengaruh signifikan terhadap kesiapan mahasiswa dalam menghadapi MEA

- Kualitas sarana-sarana dan kualitas lingkungan belajar memiliki pengaruh yang signifikan terhadap kesiapan mahasiswa dalam menghadapi MEA

- Akan tetapi secara bersama-sama kualitas pembelajaran, kualitas sarana-prasarana, dan kualitas lingkungan belajar berpengaruh signifikan terhadap kesiapan mahasiswa dalam menghadapai MEA.

Dengan demikian disarankan bagi penyelenggara pendidikan tinggi swasta agar semakin meningkatkan kualitas sumberdaya dilembaganya masing-masing untuk memperoleh hasil lulusan yang berkelas global.

\section{DAFTAR PUSTAKA}

Effendi, S. (2003). Pengelolaan Perguuran Tinggi Menghadapi Tantangan Global. Seminar Nasional Majelis Rektor Indonesai, 1-12. https://doi.org/10.1371/journal.pone.011 6342

https://forlap.ristekdikti.go.id/perguruantinggi /detail/N0YzMThEOTQtQzQ5RS00REI xLUE5RDUtRTEyODM1NUEwQzU0

Kamus Besar Bahasa Indonesia (2005) Departemen Pendidikan dan Kebudayaan Cetakan ke. 2

Kementerian Perencanaan Pembangunan Nasional (Bappenas). (2018). Jumlah Penduduk Indonesia Mencapai 265 Juta Jiwa pada Tahun 2018. Retrieved from https://databoks.katadata.co.id/datapublis h/2018/05/18/2018-jumlah-pendudukindonesia-mencapai-265-juta-jiwa

Kompas.com dengan judul "Pertumbuhan Ekonomi NTB 7,1 Persen, Melebihi Pertumbuhan Ekonomi Nasional". https://ekonomi.kompas.com/read/2018/ 04/21/134645526/pertumbuhanekonomi-ntb-71-persen-melebihipertumbuhan-ekonomi-nasional. Penulis: Mutia Fauzia Editor: Amir Sodikin

Muh Fitrah, Ruslan, H. (2018). Urgensi sistem penjaminan mutu internal terhadap peningkatan mutu perguruan tinggi. Jurnal Penjaminan Mutu, 4(1), 76-86.

Muhson, A., Wahyuni, D., \& Mulyani, E. (2012). Analisis Relevansi Lulusan Perguruan Tinggi. Jurnal Economia, 8(April), 42-52.

Republic Of Indonesia, G. The Law of Republic of Indonesia Number 7 of 2014 Concerning Trading (2014).

Republic Of Indonesia, G. The Law of Republic of Indonesia Number 20 of 2003 
Concerning National Education System (2003)

Riduwan. (2009). Skala Pengukuran Variabelvariabel Penelitian. Bandung: Alfabeta

Sagala, S. (2003). Konsep dan Makna Pembelajaran. Bnadung CV. Alfabeta

Suwarno, W. (2006). Dasar-dasar Ilmu Pendidikan. Jogjakarta: Ar-Ruzz Media

Soemanto, W. (1990). Psikologi Pendidikan. Jakarta: Rineka Cipta.

Sonhadji, A. (1992). Hubungan Simbiotik Antara Perguruan Tinggi dan Industri: Implikasi terhadap pengelolaannya. Pidato Ilmiah dalam rangka Dies Natalis ke-38 IKIP Malang Tanggal 16 Oktober 1992.

Sonhadji, A., \& Huda A.Y., M. (2014). Asesmen Kebutuhan, Pengambilan Keputusan, dan Perencanaan: Matarantai dalam Manajemen Pendidikan. Malang: Universitas Negeri Malang (UM Press)

Wangke, H. (2015). Peluang Indonesia Dalam Masyarakat Ekonomi Asean 2015. In Info Singkat Hubungan Internasional (Vol. VI, pp. 5-8). Retrieved from http://berkas.dpr.go.id/pengkajian/files/in fo_singkat/Info Singkat-VI-10-II-P3DIApril-2014-4.pdf

Widayat, P. (2018). Peran Akreditasi Dalam Menarik Minat Mahasiswa. Jurnal Penjaminan Mutu, 4(2), 199-207. 